\title{
Habermas on Modernity and Postmodernism Guenter Zoeller
}

THE TITLE of this ambitious contribution to the interpretation of our times is carefully chosen: "discourse" here means the reflective thematization of an issue that is up for critical discussion; "philosophical discourse" refers to an ongoing debate among philosophers; and "modernity" indicates the topic of this discourse: the status of Western culture since the Enlightenment. Furthermore, Habermas distinguishes philosophical modernity from modernism in the arts and from a more casual sense of modern times.

The occasion for Habermas' assessment of the history of philosophical reflection about modernity is the emergence of a cluster of movements in contemporary French thought that consider themselves to have gone beyond modernity in proclaiming and celebrating a post-Enlightenment or post-modern age. Habermas responds to postmodernism in philosophy with an account of the modernist ancestry of philosophical postmodernism. He shows that the critique of modernity has always been an integral part of philosophical modernity itself and that the radical disjunction between postmodernism and modernity is predicated on a reduced and inadequate understanding of philosophical modernism's self-critical potential.

In what follows, I will recapitulate the main points of Habermas' account of the philosophical discourse of modernity, then summarize his metacritique of philosophical postmodernism as it reflects Habermas' own theory of modernity, and finally assess the importance of Habermas' contributions for the wider debate on postmodernism.

In his theory of modernity, Habermas closely follows Hegel's analysis of the Enlightenment (23-44). Tracing the origins of philosophical modernity as far back as the Renaissance and the Reformation, Hegel had insisted that the extent of our emancipation from religious and secular tradi-

Jürgen Habermas, The Philosophical Discourse of Modernity. Twelve Lectures, translated by Frederick Lawrence. The MIT Press: Cambridge, Mass., 1987. 
tions did not become evident until late in the eighteenth century, particularly in Kant's radical critique of the metaphysical tradition. For Hegel, Kant was the first to fully articulate the modern principle of "subjectivity" (Hegel's term), with its doctrines of individualism (the infinite worth of the individual), criticism (the problematic status of traditions), autonomy (the independence of human agency from external moral authority), and idealism (the omnipresence of reason in the world). The immediate reaction to Kant's philosophy revealed the ambivalent character of modernist philosophical accomplishments. Enlightened reason provided freedom from traditional authorities but left as their only replacement abstract rational principles of theoretical, moral-practical and aesthetical knowledge with no significant integrative cultural force. Reason as systematized by Kant appeared one-sided and irrevocably separated from what it excluded from its domain. Post-Kantian philosophy was thus based on opposition, "Entzweiung" as Hegel put it, and called for some new form of unification.

Among the various innovative proposals for an emendation of Kantian philosophy, Hegel's own theory of the absolute as all-encompassing, selfrealizing spirit emerged as the most influential and challenging contribution to the post-Kantian philosophical debate. According to Hegel, what was called for was not an abandonment of the Kantian project of a critique of reason but rather its radicalization. Enlightenment reason ("Verstand") with its insistence on abstract opposition had to be integrated into a more comprehensive, speculative, form of reason ("Vernunft") that could even unify the opposition between unity and difference. Through his notion of speculative reason, Hegel was thus able to think of what Enlightenment reason excluded as other than reason as reason's own other.

For Habermas, the idea of including otherness within absolute reason provides the starting point for three distinct movements in nineteenthcentury thought: Hegelian orthodoxy with its conservative insistence on the rationality of the actual (Right Hegelians), the revolutionary transformation of speculative philosophy into a philosophy of concrete, human, political practice (Left Hegelians), and Nietzsche's utter rejection of the very concept of autonomous reason governing either the actual world or a possible, unalienated world (51-74). In Habermas' reconstruction, Nietzsche emerges as the "turning point" at which the philosophical discourse of modernity enters its postmodern phase (83-105). Before Nie- 
tzsche, the main participants in that discourse shared Kant's and Hegel's belief in reason's potential to provide its own justification through critique. Nietzsche provides an alternative concept of rationality, replacing the subjective genitive in the phrase, "critique of reason," with an objective genitive. Reason no longer enacts its own critique but is critiqued from without instead. No longer self-sufficient, reason becomes a function of the other, the non-rational.

The two main lines of contemporary philosophical development that Habermas traces to Nietzsche are Heidegger's History of Being together with Derrida's Grammatology, on one side, and Bataille's rehabilitation of the ecstatic together with Foucault's Theory of Power, on the other (131293). In Heidegger, the overcoming of "subjectivity" takes the form of a neo-mystical philosophy of unscrutinizable origins ("Ursprungsphilosophie"), a direction continued by Derrida's emphasis on writing as opposed to speech and on the unidentifiable as opposed to what can be repeated identically. In Bataille, the authority of practical reason as it appears in the rationalization of modern life, is critiqued in the name of the suppressed and marginalized erotic experience. Foucault's critique of modernity, finally, dislocates the human being from its position as the subject of history to a resultant in a depersonalized field of institutional forces.

Habermas thus articulates the two phases of the philosophical discourse of modernity in terms of two competing conceptions of reason: the Hegelian notion of reason qua spirit as substance and subject of everything actual and the Nietzschean concept of a merely instrumental rationality that stands in the service of some other force, such as life, Being, or power. Even the neo-Marxist critique of reason presented by the Frankfurt School is subsumed under this bipartite scheme (106-130). For Habermas, Horkheimer's and Adorno's work on the relapse of reason into mythical irrationality ("dialectic of Enlightenment") and their insistence on the necessary distortedness of reason follows Nietzsche's reductionist project of a natural history of culture ("genealogy of morals”).

In Habermas' presentation, the analyses of the various stages in the philosophical discourse of modernity always include a principal critique of the position under consideration. As regards Hegel and the Right and Left Hegelians, Habermas agrees with the postmodernist rejection of the meta- 
physical view of history as the self-realization of some supra-human rational spirit. He does not, though, endorse the absolute rejection of the centrality of reason in human self-understanding.

Habermas' metacritique of the postmodern critique of rationality employs three distinct arguments that he mobilizes in various combinations against each of the thinkers under discussion. In an argument that draws on the long-standing tradition of refuting the skeptic, Habermas points out the precarious status of a position that totally rejects privileging any position and thus cannot account for the alleged validity of itself, except by way of contradiction (276ff.). The second argument charges the contemporary detractors of reason with collapsing the ineluctable Kantian distinction between genesis and validity, between questions concerning the factual origin of some claim and its possible justification on grounds that cannot be reduced to its de facto origin (119ff.). The third anti-postmodernist argument, also Kantian in origin, amounts to the charge that Nietzsche and his successors are blurring the principal distinction between the three equiprimordial spheres of claim and adjudication: the cognitive sphere in which claims concerning factual correctness are raised and adjudicated, the moral-legal sphere in which claims concerning normative correctness are raised and adjudicated, and the aesthetic-critical sphere in which claims regarding artistic authenticity are raised and adjudicated $(19$, $50)$.

For Habermas, these three arguments against philosophical postmodernism constitute a minimalist theory of rationality that attempts to replace the unacceptable substantialist notion of reason as universal subject with a conception of rationality based on reason as the necessary standard of interaction between subjects that rely on each other for the recognition and adjudication of their claims (294-326; 336-367). What Habermas proposes is a paradigm shift away from the notion of reason as centered around an isolated individual (either a concrete Ego or a world spirit) towards a concept of reason as centered around supra-subjective, though not supra-human communicative interaction. Habermas sees himself inspired to this paradigm shift by indications of the foundational role of intersubjectivity that he identifies at various stages of the philosophical discourse of modernity. However, Habermas concedes that neither Hegel nor Marx nor Husserl nor Heidegger pursued the idea of communicative rationality to the theoretical radicality that he himself had taken it in his earlier two- 
volume opus, The Theory of Communicative Action. Given that The Philosophical Discourse of Modernity employs the new theory of rationality as the standard for competing views on the nature of the modern in general and the rational in particular, the anti-postmodernist argument of the book is predicated on Habermas' conviction that the universality of rational standards can be maintained in a theory that no longer invokes metaphysical guarantees.

Habermas' sustained insistence on the emancipatory potential of reason provides a welcome antidote to the fatalist, if not apocalyptic tones that characterize much contemporary Continental thought with its idolatry of such unscrutinizable entities as "Being," "Power," or "Writing." Delineating a third way between the Hegelian and the Nietzschean alternatives allows Habermas to expose the non sequitur in the move from the rejection of classical-modernist rationality to the adoption of an essentially a-rationalist philosophical postmodernism. Of particular interest should be Habermas' assessment of the generic distinction between philosophy and literature (185-210). In the face of Derrida's and his American followers' attempts to remove any principal boundaries between literature, literary criticism, and philosophy, Habermas insists on the diversity of the cultural functions exercised by each of the genres in question. In an argument that draws on his earlier neo-Kantian distinction between the three equiprimordial value spheres (science, morality and law, art and criticism), $\mathrm{Ha}-$ bermas distinguishes the world-constituting function of art, its capacity to bring about innovative perspectives, from the innerwordly problemsolving capabilities of the other two dimensions of possible claims. The aesthetization of all experience, as implied in the pantextualism of the Derrideans, is thus seen as threatening the balance in the cultural system of complementary functions; in particular, the dimension of critique according to cognitive and normative standards is seen as dissolving into an unlimited proliferation of interpretations beyond any standard of adjudication.

In discussing the respective tasks of literary criticism and philosophy, Habermas concedes that the rhetorical character of philosophy is indispensable given philosophy's task of mediating between spheres of highly specialized knowledge ("expert cultures") and the dimension of unre- 
flectedly functioning societal existence ("life world"). But for Habermas, the reliance on literary devices in philosophical argumentation does not affect its obligation to aim at the solution of problems, just as the bent towards philosophy in literary criticism is no substitute for the genuine task of a critique of artistic experience and its objects. For the contemporary cultural situation with its penchant towards interdisciplinary and intergeneric outreaches, this conviction amounts to the insight that the prerequisite for mediation between the various spheres of cultural and intellectual activity is not the collapse of disciplinary boundaries but rather their recognition as orientation marks in the exchange and mutual assessment of claims and their attempted justifications. 